\title{
Whistleblowing Disclosure Policy and Cost of Equity in ASEAN 5 Publicly Listed Companies: A New Establishment of Regional Whistleblowing Disclosure Scoring Index
}

\author{
(Pendedahan Polisi Penyelewengan dan Kos Ekuiti untuk Syarikat Tersenarai Awam di ASEAN 5. \\ Pembangunan Baru Skor Indeks Pendedahan Penyelewengan Serantau) \\ Mohd Fairuz Md. Salleh \\ (Faculty of Economics and Management, Universiti Kebangsaan Malaysia) \\ Wan Sallha Yusoff \\ (School of Business Innovation and Technopreneurship, Universiti Malaysia Perlis) \\ Norida Basnan \\ (Faculty of Economics and Management, Universiti Kebangsaan Malaysia)
}

\section{ABSTRACT}

Healthy corporate governance is necessary for attracting investor participation and alleviating corruption. Akin to other developing nations, two major challenges arise. First, Increasing foreign direct investments (FDIs) and second, controlling corruption are faced by all countries in the Association of South East Asian Nations (ASEAN) for their economic development. Phenomenal practices of whistleblowing policies in developed countries, especially in Europe and the US, have become crucial elements for modern corporate governance. Such practices also play important roles in detecting fraud and enhancing FDI and GDP growth. The aims of this study are twofold: to uncover the extent of the effects of whistleblowing disclosure quality on cost of equity (COE) and to propose whistleblowing disclosure scoring index as a new mechanism to integrate whistleblowing disclosure policy in the ASEAN region. Furthermore, a proposal for promulgating a comprehensive whistleblowing policy with inclusive internal and external programmes, which are necessary for establishing strong corporate governance, is presented. Empirical results confirm that whistleblowing disclosure quality has a significant negative relationship with COE. Our finding suggests that a uniform and comprehensive whistleblowing policy is needed to strengthen the best practices of ASEAN Corporate Governance Codes.

Keywords: Whistleblowing policy; disclosure; cost of equity; corporate governance; ASEAN

ABSTRAK

Tadbir urus korporat yang sihat adalah penting untuk menarik penglibatan pelabur luar dan mencegah rasuah. Seperti mana negara-negara membangun yang lain, terdapat dua cabaran dalam meningkatkan pembangunan ekonomi negara-negara Kesatuan Asia Tenggara (ASEAN) iaitu; meningkatkan FDI dan mengawal rasuah. Secara praktikal, polisi pendedahan penyelewengan di negara maju, terutamanya Eropah dan Amerika Syarikat mengambil kira tadbir urus korporat yang moden sebagai satu elemen penting dan berperanan untuk mencegah penipuan. Kajian ini bertujuan untuk mencapai dua perkara; pertama, sejauh manakah pendedahan penyelewengan yang berkualiti dapat mengurangkan kos ekuiti dan kedua mencadangkan indeks skor bagi pendedahan penyelewengan sebagai satu mekanisme baru untuk mengintegrasikan polisi pendedahan penyelewengan di serantau ASEAN. Kajian ini juga mengemukakan cadangancadangan untuk memperluaskan polisi pendedahan penyelewengan secara komprehensif dengan merangkumi program dalaman dan luaran di mana ianya penting untuk memperkukuhkan tadbir urus korporat. Merujuk kepada keputusan empirikal, kualiti pendedahan penyelewengan mempunyai hubungan yang signifikan negatif terhadap kos ekuiti. Keputusan kajian mencadangkan bahawa perlunya satu polisi pendedahan penyelewengan yang seragam dan komprehensif untuk memperkukuh amalan baik Tabdir Urus Korporat ASEAN.

Kata kunci: Polisi pendedahan penyelewengan; pendedahan; kos ekuiti; tadbir urus korporat; ASEAN

\section{INTRODUCTION}

Since the introduction of the Sarbanes-Oxley Act in 2002, corporate whistleblowing has been increasingly perceived as a critical element in corporate governance reforms around the world (Callahan et al. 2003). Whistleblowing refers to an initiative to disclose immoral, illegal and illegitimate practices within an organisation (Rachagan
\& Kuppusamy 2013). This disclosure is performed by former or current employees under the authority of their employers (Fasterling \& Lewis 2014) and persons or organisations (Ahmad et al. 2013) who can execute consequent actions. Whistleblowing involves two kinds: internal (report wrongdoings to someone within an organisation) or external (report wrongdoings to someone outside the organisation, such as media or government agencies) (Dworkin \& Baucus 1998). 
Most whistleblowers are motivated to report internally rather than externally because they are loyal to their organisation and prefer to reduce cost (Nielsen 2018). However, if they fail to report internally because they fail to get any response from the internal channel or fear of retaliation in subtle ways, such as being shunned by co-workers, selective downsizing, harassment by supervisors and victimisation, then whistleblowers may report externally. The increasing number of external whistleblowing incidents contributes negative effects on whistleblowers, such as physical, emotional, social and spiritual effects, and negatively impacts the ethical behaviour of organisations (Park \& Lewis 2018). As a result, investor trust and participation are reduced. Therefore, companies are advised to disclose a comprehensive whistleblowing policy in their internal reporting system and provide a clear picture related to whistleblowers' protection, encourage the internal whistleblowing process and increase investor confidence.

In Australia, the revised principles of Good Corporate Governance and Best Practice Recommendations of 2007 state that publicly listed companies should establish and disclose in their annual reports the code of conducts, which includes provisions related to whistleblowing (Lee \& Fargher 2013). In some countries, whistleblowing policy disclosure in annual reports is mandatory. For instance, all companies in the UK, US and Belgium should comply with the provisions or explain why, in specific situations, they do not comply (Hassink, De Vries \& Bollen 2007). In developing countries, such as Malaysia, whistleblowers are protected under a specific law of the Whistleblower Protection Act (WPA) of 2010 (Meng \& Fook 2011). In addition, Recommendation 1.3 of Principle 1 of the Malaysian Code on Corporate Governance 2012 states that 'the code of conduct should include appropriate communication and feedback channels which facilitate whistleblowing'. Although whistleblowing policy is commonly known in developing countries, the challenges lie on the Association of South East Asian Nations (ASEAN) 5 countries due to the lack of specific laws for whistleblower protection in the region. For example, no specific law for whistleblower protection has been promulgated in Singapore, Indonesia and Thailand (Global Integrity 2007). Notwithstanding, more than a dozen rules of protecting whistleblowers have been provided in some countries, such as Singapore (Meng \& Fook 2011). According to the 2010 APEC Economy Policy Report, whistleblower rights in the Philippines are weakly protected even though the WPA was put in place in the 14th Congress of the Philippines. The best practices of the ASEAN Corporate Governance (ASEAN-CG) Codes propose that a detailed whistleblowing policy is necessary to achieve good-quality corporate governance practices in ASEAN countries (ACMF 2013).

Similarly, in the corporate governance literature, whistleblowing policy is an element of internal reporting system and one of the effective mechanisms to combat fraud (Lee \& Fargher 2013). A great extent of whistleblowing policy in companies' code of conduct indicates that a great whistleblowing system should be put in place in such organisations. Extant literature has established the importance of whistleblowing policy disclosures in corporate governance statements to instil trust and confidence among investors. Hassink et al. (2007) argued that a code of conduct can significantly reduce unethical behaviours within organisations. Accordingly, it increases company reputation and investor expectations. Chen et al. (2009), proved that great disclosures of firm-related information decrease firms' capital cost due to their significant role in the assessment of firm value. Moreover, McKinsey surveys have concluded that institutional investors are willing to pay high premium for shares in firms with good corporate governance practices, especially when such firms are in countries that provides legal protection for investors (Holder-Webb et al. 2008). However, the inconsistent disclosure of whistleblowing policy contents among publicly listed companies provides an opportunity to examine the effects of whistleblowing policy disclosure on capital cost valuation. This issue is relevant to the ASEAN-CG standards and practices in which the objective of corporate governance is to integrate and strengthen such standards among publicly listed ASEAN companies and increase foreign direct investments in the region. Such investments achieve the predominant objectives of the ASEAN Economic Community (AEC) as a single market and production base. A uniform whistleblowing policy at the regional level can enhance managerial monitoring and minimise power abuse (Lee et al. 2018). Thus, the idiosyncratic component of cost of equity $(\mathrm{CoE})$ reduces and benefits shareholders.

This research aims to examine the effects of whistleblowing policy disclosure on the COE in ASEAN 5 publicly listed companies, namely, Malaysia, Thailand, Singapore, Indonesia and the Philippines. We expect that a detailed whistleblowing policy disclosure can enhance an efficient accounting standard enforcement regarding the prevention of unethical behaviours and reduce CoE. We also propose whistleblowing disclosure scoring index as a new mechanism to improve whistleblowing disclosure quality in ASEAN. The index is based on the relevant disclosure requirement of ASEAN-CG Scorecard and a recommended disclosure checklist provided by Standards Australia (2003), OECD Whistleblower Protection Report (2012) and the UK Whistleblowing Commission Report (2013).

Our study contributes to the existing literature in three ways. Firstly, we provide new insights into the importance of whistleblowing disclosure quality in cultivating investor interest by investigating the effects of whistleblowing policy disclosure on firms' CoE. Secondly, we extend agency theory by providing a new empirical evidence on whistleblowing policy disclosure and COE as asymmetry information problems among principles and agents. Lastly, we propose whistleblowing disclosure scoring index as a new mechanism in ASEAN 5 publicly listed companies by benchmarking with disclosure checklist provided 
by Standards Australia (2003), OECD Whistleblower Protection Report (2012) and the UK Whistleblowing Commission Report (2013).

The rest of this paper is organised as follows: Section II presents a literature review on whistleblowing policy disclosure and COE in ASEAN 5 countries. Section III extends whistleblowing disclosure scoring index and underlying research methodologies. Section IV presents the empirical results and discussion and finally offers conclusion remarks.

\section{LITERATURE REVIEW}

\section{ASEAN-CG AND WHISTLEBLOWING POLICY}

ASEAN EAC, which is established in 2015 , is a major platform that aims to improve ASEAN's regional economic agenda (ASEAN Secretariat 2008). Its main objective is to establish ASEAN as a single market and production base, with free flow of goods, services, investments, skilled labour and capital across the border of ASEAN countries. Currently, ASEAN economy is the sixth largest in the world and third largest in Asia with a combined gross domestic product of US\$2.55 trillion in 2016 (ASEAN Secretariat 2017).

To achieve EAC objectives, the ASEAN Capital Markets Forum (ACMF) was established in 2004. 'Attracting greater investor participation' is among the six key priorities highlighted in the first phase of ACMF Action Plan 20162020 (ACMF 2009). Thus, the ASEAN-CG Scorecard was created to improve investor confidence in the quality of the corporate governance standards and practices among ASEAN publicly listed companies. Six ASEAN countriesMalaysia, Thailand, Singapore, Indonesia, the Philippines and Vietnam-have agreed to participate in this initiative.

During the seven years' experience in implementing ASEAN-CG (starting from 2012), six participating countries have faced obstacles and constraints in balancing their national characteristics to meet the integrated objectives of ACMF and achieve international best practices of ASEANCG. However, companies still face challenges to comply with a comprehensive disclosure of whistleblowing policy, as one of the disclosure and transparency improvements in ASEAN (ACMF 2013). In the ASEAN-CG Scorecard Country Reports and Assessments 2012-2013, Asian Development Bank reported that all ASEAN-CG participating countries, except Singapore, failed to disclose a comprehensive whistleblowing policy (ASEAN 2013). Similarly, in 2014 and 2015, establishing whistleblowing policies is still a critical area for improvement in all participating countries, except Singapore (ACMF 2015).

In Malaysia, the number of companies that provide a procedure in place for employees to complain about illegal and unethical behaviours decreased from $67 \%$ in 2014 to $58 \%$ in 2015 (ACMF 2015). A similar reduction trend occurred in 2015, where the number of companies with policies and procedures in protecting employees or individuals from retaliation when they reveal illegal and/or unethical behaviours, have decreased from $52 \%$ in 2014 to $46 \%$. A significant reduction in the whistleblower protection disclosure within publicly listed Malaysian companies in other ways, reflect investor uncertainty on organisations' ethical behaviour, which, in turn, reflects investment decisions.

Hassink et al. (2007) conducted a research entitled 'A Content Analysis of Whistleblowing Policies of Leading European Companies.' They found that a detailed whistleblowing policy disclosure might significantly affect company image on criminal and ethical behaviours. Thus, in achieving great investor participation, ASEAN member countries must provide a uniform set of whistleblowing policies with a comprehensive content that specify external and internal whistleblowing procedures and robust whistleblower protection (Hassink et al. 2007).

\section{WHISTLEBLOWING DISCLOSURE QUALITY AND COE}

Researchers have been focusing on whistleblowing policy disclosure since the 1980s. Two perspectives can also be considered. Firstly, whistleblowing disclosures signal an effective whistleblowing system in organisations. For example, Somers (2001) and Adams, Tashchian and Shore (2001) found that employees from companies that disclose ethical codes experience few wrongdoings because they treat themselves more ethically than companies without such ethical codes. Some disclosure serves as an effective whistleblowing system in companies. Moreover, whistleblowing disclosure mitigates problems due to fraud and corruption because the disclosure encourages whistleblowers to blow the whistle (Lee \& Fargher 2013). A detailed whistleblowing policy disclosure signals a good whistleblowing system in place and influences investors to take large positions in firm share. The positive attitude of investors leads to high demand for firm security, which raises the current prices of firm share and reduces the COE. Thus, shareholders who are confident with firms' ability to curb fraud and corruption may be willing to accept a low risk premium, thus reducing the COE (Ramly 2012). Secondly, a rising probability of whistleblowing disclosure may restrict other organisation members' doubtful activities and increase risks and further constraints on a wide scope of organisation activities (Schmidt 2005). Consequently, capital cost increases. Thus, the argument on to what extent the level of whistleblowing policy disclosure influences the COE is still questionable in the accounting and financial literature.

The theoretical underpinnings of this study are mainly provided by agency theory. The theory suggests that high disclosure of accounting information, such as whistleblowing policy in the Code of Conduct, resolves agency problems between the management and owner. The attempt to reduce information asymmetry between managers and investors reduces the idiosyncratic 
component of CoE (Healy \& Palepu 2001). Therefore, the following hypothesis is proposed.

$\mathrm{H}_{1} \quad$ Whistleblowing policy disclosure negatively affects CoE.

\section{METHODOLOGY}

This study focuses on all companies from ASEAN 5 markets (except Singapore security market) listed in each country's main market, such as Bursa Malaysia, Stock Exchange of Thailand, Indonesia Stock Exchange and Philippine Stock Exchange. Singapore security market is excluded from this research due to its different economic size and market maturity (Singapore as a developed country). All finance-related firms, insurance, closed-fund banks and unit trust companies are excluded from the sample because the high leverage ratios of financial firms to non-financial firms may affect our results (Boubakri et al. 2012). Financial firms also have different compliance, financial reporting standards and regulatory requirements and framework from non-financial firms (Lee \& Fargher 2013). In addition, we excluded companies that do not disclose their whistleblowing policies on their annual reports and companies with missing values on financial measurement data.

Through the ASEAN-CG codes and practices, whistleblowing data are readily available as voluntary disclosure at firms' annual reports. The annual financial data are gathered from Thomson Reuters Datastream. 2015 is selected as the study period to represent the period after the implementation of the ASEAN-CG initiatives in ASEAN 5 countries. Table 1 summarises the sampling data selection.

TABLE 1. Sample selection

\begin{tabular}{lcccc}
\hline \multicolumn{1}{c}{ Description } & \multicolumn{3}{c}{ Number of companies } \\
\cline { 2 - 5 } & Malaysia & Thailand & Indonesia & Philippines \\
\hline Initial selection of companies from main market & 919 & 705 & 558 & 269 \\
Less: & 51 & 58 & 88 & 37 \\
$\begin{array}{l}\text { Finance-related firms } \\
\text { Companies with missing values on financial measurement data }\end{array}$ & 609 & 374 & 348 & 130 \\
$\quad \quad$ Companies that do not disclose their whistleblowing policies & 48 & 72 & 45 & 67 \\
$\quad$ on their corporate governance statement & 211 & 201 & 77 & 35 \\
$\begin{array}{l}\text { Final sample of companies with detailed, publicly available } \\
\text { whistleblowing policies and financial data }\end{array}$ & & \multicolumn{3}{c}{524} \\
\hline $\begin{array}{l}\text { Total sample size } \\
\text { Percentage }\end{array}$ & \multicolumn{3}{c}{$21.4 \%$} \\
\hline
\end{tabular}

\section{MEASUREMENT OF VARIABLES}

On the basis of the data availability in the four ASEAN countries, this research uses short-term stock prices and analysts' earnings forecasts by employing modified economy-wide growth model $\left(\gamma_{\mathrm{GM}}\right)$ proposed by Gode and Mohanram (2003) as a proxy to COE. The short-term growth rates are captured from $\mathrm{I} / \mathrm{B} / \mathrm{E} / \mathrm{S}$ database. The formula is as follows:

$$
\gamma_{G M}=A+\sqrt{A^{2}+\frac{E P S_{1}}{P_{o}}}\left(g_{s t}-g_{a e}\right)
$$

where

$$
A=\frac{g_{a e}+\frac{D P S_{1}}{P_{o}}}{2}
$$

DPS is the dividend per share, and $g_{s t}$ is a short-term growth. $\gamma_{\mathrm{GM}}$ considers that short-term growth can be set equal to the following:

$$
g_{s t}=\frac{E P S_{2}-E P S_{1}}{2}
$$

\section{MEASUREMENT FOR WHISTLEBLOWING DISCLOSURE QUALITY}

This study employs whistleblowing disclosure scoring index (WBDI) as a proxy for whistleblowing disclosure quality. Table 2 reports that WBDI is directly developed through self-constructed index on the basis of voluntary disclosure scorecard. The scorecard is based on the relevant disclosure requirement of ASEAN-CG Scorecard and a recommended disclosure checklist provided by Standards Australia (2003), OECD Whistleblower Protection Report (2012) and the UK Whistleblowing Commission Report (2013). For example, Standards Australia (2003) recommends that reports should be kept confidential and secured within the law. Considering this recommendation, we have included an item in the scorecard (item 6 in Table 2 ) that examines whether companies have disclosed that reports should be kept confidential and secured within the law. Standards Australia (2003) also recommends the provision of a whistleblowing protection officer. Given this recommendation, an item on our scorecard examines whether companies have disclosed the appointment of a whistleblowing protection officer (item 14 in Table 4). The scorecard is applied to the whistleblowing policy 
report of each company to determine the extent of whistleblowing disclosures. For each disclosure item, the existence of the disclosure is coded ' 1 ' if present and ' 0 ' otherwise. We adopt a weighted-average index score for all disclosures made for each firm. A total of 14 disclosure items are examined from the whistleblowing policies of companies in the sample, giving a maximum score of 14. High scores represent great overall whistleblowing disclosure.

Table 2 presents the frequency of disclosed items by companies in the samples. From the data, all companies in Malaysia provide a statement that companies are generally committed to a culture of corporate compliance and ethical behaviour. Companies in Indonesia disclose with an average score of 53.25 (Table 2, No. 1). Companies that separate communication channels to receive complaints from internal and external parties are recorded below average, in which the highest score is only 57.35 (Table 2, No. 2). The scope of the whistleblowing policy applied to employees is recorded higher (Table 2, No. 3) than the policy score that extends to non-employees (Table 2, No. 4) for all ASEAN 5 countries, except for Malaysia, which shows that 49.76 is the policy score for employees and 51.18 for non-employees.

TABLE 2. Whistleblowing disclosure scoring index

\begin{tabular}{|c|c|c|c|c|c|c|}
\hline \multirow[t]{2}{*}{ No. } & \multirow[t]{2}{*}{$\begin{array}{l}\text { Disclosure Item of Whistleblowing } \\
\text { Policy Scorecard }\end{array}$} & \multirow[t]{2}{*}{ Source * } & \multicolumn{4}{|c|}{$\begin{array}{c}\text { Frequency of Item Reported by Companies in } \\
\text { the Sample }(n=524)\end{array}$} \\
\hline & & & $\begin{array}{l}\text { Malaysia } \\
\%\end{array}$ & $\begin{array}{l}\text { Thailand } \\
\%\end{array}$ & $\begin{array}{l}\text { Indonesia } \\
\%\end{array}$ & $\begin{array}{l}\text { Philippines } \\
\%\end{array}$ \\
\hline 1 & $\begin{array}{l}\text { A general statement of the entity's commitment to a } \\
\text { ulture of corporate compliance and ethical behaviour }\end{array}$ & $1,2,3$ & 100.00 & 78.26 & 53.25 & 73.48 \\
\hline 2 & $\begin{array}{l}\text { A statement that separates communication channels to. } \\
\text { receive complaints from internal and external parties is } \\
\text { provided }\end{array}$ & $1,2,3$ & 57.35 & 56.52 & 50.65 & 27.27 \\
\hline 3 & $\begin{array}{l}\text { Clearly define a scope that applies to employees } \\
\text { (including contractors and consultants) }\end{array}$ & $1,2,3$ & 49.76 & 43.48 & 38.96 & 63.16 \\
\hline 4 & $\begin{array}{l}\text { Clearly define a scope that applies to non-employees } \\
\text { (customers, general public) }\end{array}$ & $1,2,3$ & 51.18 & 21.74 & 27.27 & 47.37 \\
\hline 5 & $\begin{array}{l}\text { A statement of the benefits and importance to the entity } \\
\text { of having a whistleblowing mechanism }\end{array}$ & 1 & 45.50 & 13.04 & 18.18 & 15.79 \\
\hline 6 & $\begin{array}{l}\text { A statement that reporting should be kept confidential } \\
\text { and secured within the law }\end{array}$ & 1,3 & 56.40 & 52.17 & 25.97 & 36.84 \\
\hline 7 & A guarantee that whistleblowers must receive feedback & 1 & 49.76 & 13.04 & 32.47 & 15.79 \\
\hline 8 & $\begin{array}{l}\text { Description of the specific protection given and the } \\
\text { actions that should be taken }\end{array}$ & $1,2,3$ & 48.82 & 43.48 & 44.16 & 12.53 \\
\hline 9 & $\begin{array}{l}\text { A description of the types of concerns, in which } \\
\text { whistleblowing mechanisms are appropriate to use }\end{array}$ & 1 & 49.76 & 34.78 & 41.56 & 5.26 \\
\hline 10 & Guidelines on who to report to & 1 & 48.34 & 34.78 & 18.18 & 15.26 \\
\hline 11 & Guidelines on how to report & 1 & 48.34 & 30.43 & 16.88 & 15.26 \\
\hline 12 & $\begin{array}{l}\text { A commitment to regularly review whistleblowing } \\
\text { programmes for effectiveness }\end{array}$ & $1,2,3$ & 20.38 & 4.35 & 16.88 & 3.42 \\
\hline 13 & No retaliation by company, if report is made in good faith & $1,2,3$ & 29.86 & 26.09 & 15.58 & 5.26 \\
\hline 14 & $\begin{array}{l}\text { A commitment to appoint and maintain an appropriately } \\
\text { qualified whistleblower protection officer is accessible to } \\
\text { all staff }\end{array}$ & 1 & 12.32 & 8.7 & 53.25 & 5.26 \\
\hline
\end{tabular}

Comparatively, few disclosures are provided by companies on the benefits of whistleblowing mechanism (Table 2, No. 5), feedback to whistleblowers (Table 2, No. 7), commitment to review whistleblowing programmes (Table 2, No. 12) and commitment to appoint and maintain an appropriately qualified whistleblower protection officer (Table 2, No. 14). With regard to confidentiality (Table 2, No. 6), protection (Table 2, No. 8) and retaliation (Table 2, No 13), companies from Malaysia and Thailand report higher score than those from Indonesia and the Philippines.
The same trend is recorded for the guidelines on the types of whistleblowing mechanisms (Table 2, No. 9), who to report to (Table 2, No. 10) and how to report (Table 2 , No. 11). Overall, the descriptive data suggests that most firms in the sample do not provide comprehensive policy disclosures. This finding is consistent with the recommendations from international standards whistleblowing disclosure checklist for their effective whistleblowing system. 


\section{CONTROL VARIABLES}

The selection of control variables included in this study is primarily based on prior studies. The control variables are firm size, leverage (LEV), return on assets (ROA) and market-to-book ratio (MTB).

Firm Size Firm size is measured on the basis of the natural $\log$ of assets (LTA). According to previous literature, firm size is inversely related to equity and default risk. Large firms have low capital cost because they enjoy great stability (Gray et al. 2009; Li et al. 2009; Ramly 2012).

LEV LEV is measured by the ratio of the total liabilities to total assets. Modigliani and Miller (1958) stated that firms' COE increases with its debt - equity ratio. The greater the financial leverage, the greater the demand for monitoring and disclosure and the higher the agency costs arising from managerial discretion to shift resources away from shareholders and the greater the demand for monitoring and disclosure; thus, the higher the COE (Gray et al. 2009; Li et al. 2009; Ramly 2012).

ROA ROA is measured as operating income to total assets. ROA is a proxy for company performance. Profitable firms decrease default risk. Hence, prior empirical studies document a negative association between firm profitability and COE (Gray et al. 2009; Li et al. 2009; Ramly 2012).

MTB Ratio This ratio is measured by the market value of common share to the book value of common share. MTB ratio has a negative relationship with COE because high book-to-market firms are expected to have high ex-post realised returns. Moreover, firms with high MTB ratio are expected to have high share prices and investment opportunities (Fama \& French 1997). Hence, high investment opportunities are associated with high long-term growth in earnings and cash-flows. Thus, COE is expected to be low for high MTB firms.

Given this discussion, the following model is estimated to analyse the extent of whistleblowing disclosure quality and COE.

$$
\begin{aligned}
\Upsilon_{\mathrm{GM}}= & \beta_{0}+\beta_{1} \text { WBDI }+\beta_{2} \mathrm{LTA}+\beta_{3} \mathrm{LEV}+\beta_{4} \mathrm{ROA}+ \\
& \beta_{5} \mathrm{MTB}+\varepsilon,
\end{aligned}
$$

where WBDI and financial variables are as previously defined. $\beta_{0} \ldots \beta_{5}$ represent regression coefficients, and $\gamma$ represents the error term. Moreover, $\Upsilon_{\mathrm{GM}}$ is the modified economy-wide growth model. Table 3 provides a definition of the research variables of this study.

\begin{tabular}{|c|c|c|}
\hline Variable & Symbol & Definition \\
\hline Cost of equity & $\Upsilon_{\mathrm{GM}}$ & $\begin{array}{l}\text { Modified economy-wide growth model measured by short-term stock } \\
\text { prices and analysts' earnings forecasts }\end{array}$ \\
\hline $\begin{array}{l}\text { Whistleblowing disclosure } \\
\text { scoring index }\end{array}$ & WBDI & $\begin{array}{l}\text { Percentage of the sum of the scores awarded for each item in the WBDI } \\
\text { (i.e. the sum of the scores awarded divided by the total number of } \\
\text { items in the WBDI [maximum score]) }\end{array}$ \\
\hline Total assets & TA & Natural LTA \\
\hline Leverage & LEV & Ratio of total liabilities to total assets \\
\hline Return on assets & ROA & Ratio of operating income to total assets \\
\hline Market-to-book ratio & MTB & Ratio of market value of common share to book value of common share \\
\hline
\end{tabular}

TABLE 3. Definition of research variables

\section{RESULTS}

Table 4 presents the descriptive statistic results of the overall COE, WBDI and control variables. The means of COE ranges from 0.373 to 2.790 , with companies in the Philippines representing the highest mean. Based on the full sample $n=524$, ASEAN 5 firms have adopted slightly below $50 \%$ of the desirable whistleblowing disclosure quality. Firms in Malaysia have commendable standards of whistleblowing disclosure quality, whereas those in the Philippines have a deplorable quality as evidenced by the lowest score of 0.182 . These results indicate that ASEAN 5 countries (except Singapore) lack in whistleblowing disclosure quality, and no standard integration is provided among these countries. Certain firms still fall behind the desirable ASEAN-CG standards and practices.
TABLE 4. Descriptive analysis

\begin{tabular}{lcccc}
\hline & \multicolumn{4}{c}{ Mean } \\
\cline { 2 - 5 } Variable & Malaysia & Thailand & Indonesia & Philippines \\
\hline$\Upsilon_{\text {GM }}$ & 0.373 & 2.782 & 1.819 & 2.790 \\
WBDI & 0.482 & 0.328 & 0.298 & 0.182 \\
TA & 6.381 & 7.526 & 10.292 & 8.065 \\
LEV & 0.449 & 0.820 & 0.562 & 0.529 \\
MTB & 2.933 & 5.503 & 4.144 & 2.802 \\
ROA & 0.079 & 0.077 & 0.094 & 0.078 \\
\hline
\end{tabular}

\section{REGRESSION RESULTS}

Table 5 provides the regression results on the impact of WBDI on $\Upsilon_{\mathrm{GM}}$ after controlling for the effects of firm size, LEV, MTB ratio and firm performance. WBDI has a significant negative relationship with $\Upsilon_{\mathrm{GM}}$ at $1 \%$ to $5 \%$ 
TABLE 5. Direct relationship between COE and WBDI

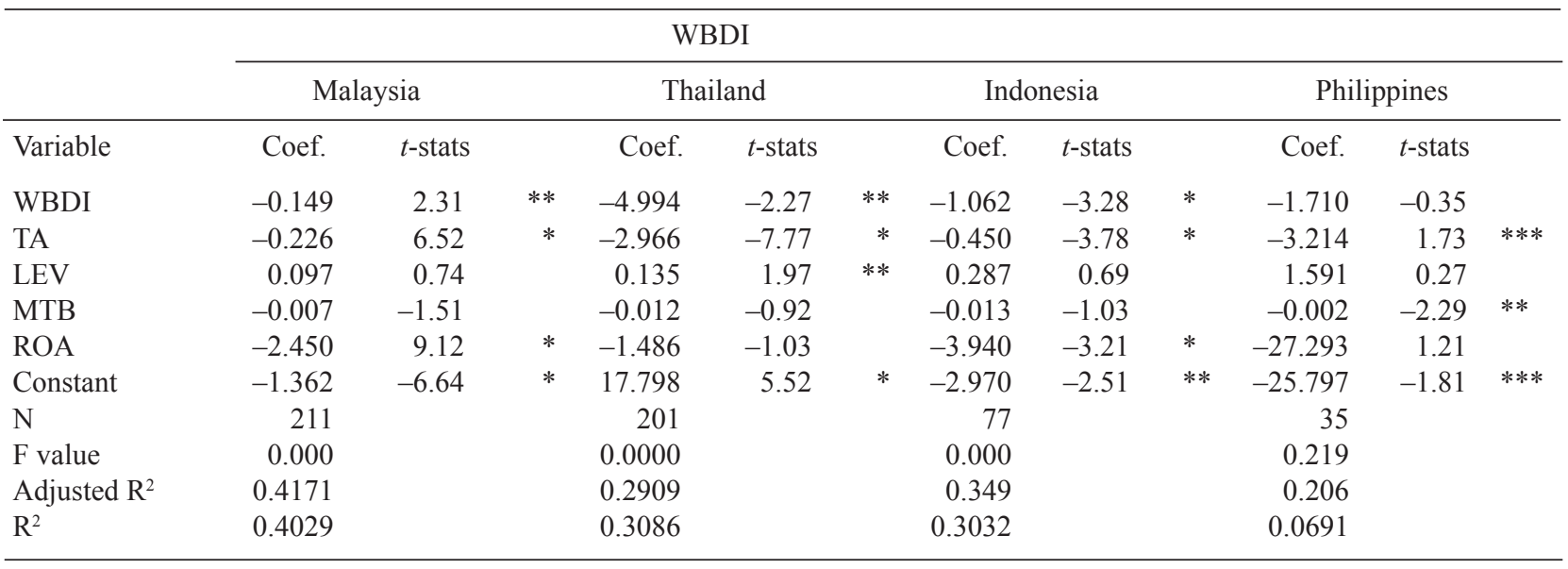

Note: An asterisk (*) indicates that the given variable is statistically significant up to $1 \%$ significance level, ** for $5 \%$ significance level and $* * *$ for $10 \%$ significance level.

level for all ASEAN 5 countries, except for the Philippines. This finding suggests that good whistleblowing disclosure quality predicts low $\Upsilon_{\mathrm{GM}}$, thus supporting H1. Although WBDI and $\Upsilon_{G M}$ are insignificant in listed companies in the Philippines, the coefficient is negative at -1.710 . Firm size (TA), MTB and ROA have significant negative relationships with $\Upsilon_{\mathrm{GM}}$, indicating that large firms with high investment opportunities likely enjoy low $\Upsilon_{\mathrm{GM}}$. Moreover, company LEV has a significant positive relationship with $\Upsilon_{\mathrm{GM}}$. This result is in line with the expectation that the greater the financial leverage, the greater the demand for monitoring and disclosure and the higher the agency costs arising from managerial discretion to shift resources away from shareholders. Thus, $\Upsilon_{\mathrm{GM}}$ is high (Gray et al. 2009; Li et al. 2009; Ramly 2012).

\section{MANAGERIAL IMPLICATION}

This study attempts to explain the effects of whistleblowing policy disclosure on the COE of 524 companies from ASEAN 5 market (except Singapore security market). Those listed in each country's main market are Bursa Malaysia, Stock Exchange of Thailand, Indonesia Stock Exchange and Philippine Stock Exchange. By introducing a new whistleblowing disclosure scoring index to the literature, we intend to obtain evidence that whistleblowing quality plays an important role in increasing FDI and reducing COE. Whistleblowing quality is assessed using a self-developed WBDI comprising 14 item scores. The quality measures are derived from the provisions of the ASEAN-CG Scorecard; a recommended disclosure checklist provided by Standards Australia (2003), OECD Whistleblower Protection Report (2012) and the UK Whistleblowing Commission Report (2013); and various prior studies. Regression results indicate that firms with high-quality whistleblowing disclosure have low COE. Furthermore, this research finds that, on average, ASEAN 5 firms have adopted slightly below $50 \%$ of the desirable whistleblowing disclosure quality, thus recommending improvement.

We suggest that ASEAN 5 publicly listed companies should disclose a clear and detailed whistleblowing policy in their annual report to reduce $\mathrm{CoE}$ and attract many investors. Whistleblowing policy disclosure on the benefits of whistleblowing mechanism, feedback to whistleblowers, commitment to review whistleblowing programmes and commitment to appoint and maintain an appropriately qualified whistleblower protection officer must also be highlighted by ASEAN 5 publicly listed companies because attention to disclosure is decreasing. We propose ACMF to provide WBDI as a new mechanism or a comprehensive guideline for ASEAN 5 countries in achieving a uniform whistleblowing policy. Such a policy is an initiative to improve the best practice of ASEAN Code of Corporate Governance. Furthermore, we propose a mandatory provision for disclosing the details of whistleblowing policy for limited private companies in their annual report. This provision can train their employees about reporting suspected violations.

This study makes several noteworthy contributions to the accounting and finance literature. Firstly, the empirical findings provide a new understanding on the effects of whistleblowing disclosure quality on $\mathrm{CoE}$, especially in the case of ASEAN 5 countries. Secondly, we provide a new whistleblowing policy disclosure scoring index as an empirical guideline to academicians for future research. Lastly, we extend the agency theory as an underpinning theory in explaining the effects of whistleblowing disclosure quality on $\mathrm{CoE}$. However, our research also has limitations. In this study, we do not measure the effects of publicly listed Vietnamese companies due to the difficulty in capturing whistleblowing data from most of their annual reports. Thus, this limitation must be addressed in future research. 


\section{CONCLUSION}

Whistleblowing has already demonstrated tools of sound corporate governance to fight against corruption, captivate FDI for economic growth and protect regional vulnerability from financial crisis. Various regional communities and forums have adopted whistleblowing policies and guidelines, such as Australian Standards (2003), EU Resolution 2060 and Guiding Principles for Whistleblower Protection Legislation 2010 recommended by the G20 Anti-Corruption Working Group, as well as international and national initiatives. ASEAN is no longer an exception. Although the importance of effective implementation of corporate governance has already been emphasised in various ASEAN documents, whistleblowing policy is a recent and incomprehensive element that has taken place through ASEAN-CG Scorecard, which covers the OECD Corporate Governance Principles regarding whistleblowing. ASEAN-CG Scorecard Country Report and Assessment of 2013-2014 rightly mentions that companies in member states, such as Indonesia, Malaysia, the Philippines, Thailand and Vietnam, still face challenges in disclosing whistleblowing. Therefore, whistleblowing policy disclosure requires improvement from these poor areas. Policies and procedures to protect whistleblowers also need attention by considering the provided suggestions and proposed policy because policy is more effective than acts and codes.

\section{ACKNOWLEDGEMENT}

We would like to thank the Ministry of Education of Malaysia under the FRGS Scheme Phase FRGS/1/2017/ SS01/UNIMAP/03/2 for the fund given to complete this research.

\section{REFERENCES}

ACMF. 2013. ASEAN Corporate Governance Scorecard: Country Reports and Assessments 2012-2013. Mandaluyong City, Philippines: Asian Development Bank.

ACMF. 2014. ASEAN Corporate Governance Scorecard: Country Reports and Assessments 2013-2014. Mandaluyong City, Philippines: Asian Development Bank.

ACMF. 2015. ASEAN corporate Governance Scorecard: Country Reports and Assessments 2015. Mandaluyong City, Philippines: Asian Development Bank.

ACMF. 2009. The Implementation Plan. Mandaluyong City, Philippines: Asian Development Bank.

Adams, J.S., Tashchian, A. \& Shore, T.H. 2001. Codes of ethics as signals for ethical behavior. Journal of Business Ethics 29(3): 199-211.

Ahmad, A.S., Smith, M. \& Ismail, Z. 2013. Internal whistleblowing intentions by internal auditors: A prosocial behaviour perspective. Malaysian Accounting Review 12(1): 145182.

Asia Pacific Economic Cooperation. 2010. APEC Economic Policy Report. APEC Economic Committee.
ASEAN Secretariat. 2008. Asean Economic Community Blueprint. Association of Southeast Asian Nations.

ASEAN Secretariat. 2017. ASEAN Economic Progress 19672017.

Australian Standards. 2003. Whistleblower protection programs for entities. Sydney: The Council of Standards Australia.

Boubakri, N., Guedhami, O., Mishra, D. \& Saffar, W. 2012. Political connections and the cost of equity capital. Journal of Corporate Finance 18(3): 541-559.

Callahan, E.S., Dworkin, T.M. \& Lewis, D. 2003. Whistleblowing: Australian, UK, and US Approaches to disclosure in the public interest. Virginia Journal of International Law 44(3): 879-912.

Chen, K.C., Chen, Z. \& Wei, K.J. 2009. Legal protection of investors, corporate governance, and the cost of equity capital. Journal of Corporate Finance 15(3): 273-289.

Dworkin, T.M. \& Baucus, M.S. 1998. Internal vs. external whistleblowers: A comparison of whistleblowering processes. Journal of Business Ethics 17(12): 1281-1298.

Fama, E.F. \& French, K.R. 1997. Industry costs of equity. Journal of Financial Economics 43(2): 153-193.

Fasterling, B. \& Lewis, D. 2014. Leaks, legislation and freedom of speech: How can the law effectively promote publicinterest whistleblowing? International Labour Review 153(1): 71-92.

Global Integrity. 2007. Global Integrity Report. Washington, DC: Global Integrity.

Gode, D. \& Mohanram, P. 2003. Inferring the cost of capital using the Ohlson-Juettner model. Review of Accounting Studies 8: 399-431.

Gray, P., Koh, P.S. \& Tong, Y.H. 2009. Accruals quality, information risk and cost of capital: Evidence from Australia. Journal of Business Finance \& Accounting 36(1-2): 51-72.

Hassink, H., De Vries, M. \& Bollen, L. 2007. A content analysis of whistleblowing policies of leading European companies. Journal of Business Ethics 75(1): 25-44.

Healy, P.M. \& Palepu, K.G. 2001. Information asymmetry, corporate disclosure, and the capital markets: A review of the empirical disclosure literature. Journal of Accounting and Economics 31(1-3): 405-440.

Holder-Webb, L., Cohen, J., Nath, L. \& Wood, D. 2008. A survey of governance disclosures among US firms. Journal of Business Ethics 83(3): 543-563.

Lee, G. \& Fargher, N. 2013. Companies' use of whistleblowing to detect fraud: An examination of corporate whistleblowing policies. Journal of Business Ethics 114(2): 283-295.

Lee, G., Pittroff, E. \& Turner, M.J. 2018. Is a uniform approach to whistleblowing regulation effective? Evidence from the United States and Germany. Journal of Business Ethics $1-24$.

Li, Y., Stokes, D. J., Taylor, S.L. \& Wong, L. 2009. Audit quality, accounting attributes and the cost of equity capital. Accounting Attributes and the Cost of Equity Capital. Available at SSRN: https://ssrn.com/abstract=1481823 or http://dx.doi.org/10.2139/ssrn.1481823

Meng, T.P. \& Fook, O.S. 2011. Comparative analysis of whistleblower protection legislations in England, USA and Malaysia. African Journal of Business Management 5(27): 11246-11255.

Modigliani, F. \& Miller, M.H. 1958. The cost of capital, corporation finance and the theory of investment. The American Economic Review 48(3): 261-297. 
Nielsen, R.P. 2018. Reformed national security internal whistleblowing systems and external whistleblowing as countervailing ethics methods. Administration \& Society

OECD. 2012. Whistleblower protection: Encouraging reporting. Available at http://www. oecd.org/cleangovbiz/ toolkit/50042935.pdf.

Park, H. \& Lewis, D. 2018. The negative health effects of external whistleblowing: A study of some key factors. The Social Science Journal 55(4): 387-395.

PCaW. 2013. The whistleblowing commission: Report on the effectiveness of existing arrangements for workplace whistleblowing in the UK. Public Concern at Work.

Rachagan, S. \& Kuppusamy, K. 2013. Encouraging whistleblowing to improve corporate governance? A Malaysian initiative. Journal of Business Ethics 115(2): 367-382.

Ramly, Z. 2012. Impact of corporate governance quality on the cost of equity capital in an emerging market: Evidence from Malaysian listed firms. African Journal of Business Management 6(4): 1733-1748.

Schmidt, M. 2005. "Whistleblowing" regulation and accounting standards enforcement in Germany and Europe - An economic perspective. International Review of Law and Economics 25(2): 143-168.
Somers, M.J. 2001. Ethical codes of conduct and organizational context: A study of the relationship between codes of conduct, employee behavior and organizational values. Journal of Business Ethics 30(2): 185-195.

Mohd Fairuz Md. Salleh

Faculty of Economics and Management

Universiti Kebangsaan Malaysia

43600 UKM Bangi, Selangor, MALAYSIA.

E-Mail: fairuz@ukm.edu.my

Wan Sallha Yusoff (corresponding author)

School of Business Innovation and Technopreneurship

Universiti Malaysia Perlis

01000 Kangar, Perlis, MALAYSIA.

E-Mail:wansallha@unimap.edu.my

Norida Basnan

Faculty of Economics and Management

Universiti Kebangsaan Malaysia

43600 UKM Bangi, Selangor, MALAYSIA.

E-Mail: norida@ukm.edu.my 